\title{
Odrazi Holbeinove slike Tijelo mrtvog Krista u grobu u romanima Idiot i Braća Karamazovi Fjodora Mihajloviča Dostojevskog
}

Daniel Miščin*

\begin{abstract}
Sažetak
Slika Hansa Holbeina Tijelo mrtvoga Krista u grobu imala je snažan utjecaj na refleksiju o mogućnosti uskrsnuća u kasnom djelu Fjodora Mihajloviča Dostojevskoga. Tom se slikom posve izravno i intenzivno bave likovi romana Idiot, a rasprava o Holbeinovoj slici u djelu Dostojevskoga najčešće se ograničava na taj roman. Usuprot tomu, autor u članku istražuje mogućnost da Dostojevski u romanu Idiot nije zaključio raspravu o Holbeinovoj slici. Usporedna analiza tekstova dvaju romana ostavlja mogućnost da je rasprava o mrtvom tijelu starca Zosime u romanu Braća Karamazovi zapravo nastavak rasprave Dostojevskoga o Holbeinovoj slici Tijelo mrtvoga Krista u grobu.
\end{abstract}

Ključne riječi: Fjodor Dostojevski; Hans Holbein; Idiot; Braća Karamazovi; kenoza; Krist; smrt

\section{Uvod}

Kritička literatura o Dostojevskom rado ističe njegovu fascinaciju slikom Tijelo mrtvoga Krista u grobu Hansa Holbeina. ${ }^{1}$ To svakako ne može biti iznenađenjem jer, koliko god je ta Holbeinova slika bila jedini razlog dolaska Dostojevskoga u Basel 24. kolovoza 1867. (Bitjugova et al., 1999, 129), ušla je u njegov svijet još u vrijeme dječaštva, i to sa stranica Karamzinova djela Pisma ruskoga putnika. Doduše, ondje je ta slika opisana vrlo šturo, ali nema sumnje što je ključno u tom opisu: »U Kristu skinutom s križa, nema ničega božanskoga« (Karamzin, 1984, 98). ${ }^{2}$ Dostojevskoga je pred Holbeinovom slikom potreslo

* Izv. prof. dr. sc. Daniel Miščin, Fakultet filozofije i religijskih znanosti Sveučilišta u Zagrebu. Adresa: Jordanovac 110, 10000 Zagreb, Hrvatska. ORCID iD: https://orcid.org/0000-00030422-3124. E-adresa: daniel.miscin@ffrz.unizg.hr

1 Hans Holbein mlađi: Tijelo mrtvoga Krista u grobu (1521.-1522.), ulje i tempera na lipovu drvu dimenzija 30,5 cm x $200 \mathrm{~cm}$, Kunstmuseum Basel.

2 Citati na hrvatskom jeziku koji su preuzeti iz publikacija na drugim jezicima prijevod su autora članka. 
baš to: dramatična odsutnost svakoga biljega transcendencije s Kristova mrtvoga tijela, Holbeinovo svođenje Sina Božjega na puki leš (Dostojevskaja, 1987, 186). Temeljna implikacija toga dojma glasi: ako u Kristu doista nema ničega božanskoga, kako je moguće sačuvati vjeru u njegovo uskrsnuće? Srasla s prodornošću toga pitanja, Holbeinova je slika usmjeravala pero Dostojevskoga na ključnim mjestima njegova zreloga opusa. S obzirom na to da je odmah nakon povratka iz Basela Dostojevski počeo stvarati roman Idiot, nije neobično da se žarište rasprave o Holbeinovoj slici nalazi upravo u tom romanu. Doista, prva se zamisao romana Idiot u životopisu Dostojevskoga može datirati samo četiri dana nakon boravka u Baselu, a točno mjesec dana nakon toga, 24. rujna 1867., nastao je prvi napisani plan romana. Između 23. i 31. prosinca te godine Dostojevski je započeo pisati roman. S obzirom na te okolnosti, ne čudi što se kritička refleksija o toj slici u opusu Fjodora Mihajloviča nerijetko ograničava isključivo na taj roman. Unatoč načelnoj dopustivosti takva postupka i ne sporeći pritom važnost Holbeinove slike za tekst romana, valjalo bi ipak preispitati drukčiju i širu tezu, koja glasi: roman Idiot nije ni posljednja riječ ni vrhunac refleksije Dostojevskoga o Holbeinovoj slici Tijelo mrtvoga Krista u grobu. Štoviše, misao Dostojevskoga o toj slici svoj zenit ne doseže u tom romanu, nego tek na stranicama njegova posljednjega romana. No, valja odmah upitati: Je li ta teza uopće moguća, s obzirom na to da se, za razliku od romana Idiot, u romanu Braća Karamazovi ne spominju ni Holbein ni njegova slika? To bi značilo da je možda i "potajice" Dostojevski morao prenijeti Holbeinovu sliku iz jednoga romana u drugi. Ako je to točno, onda je ključno analizirati kako je to Dostojevski učinio i na temelju čega je moguće zaključiti da on u romanu Braća Karamazovi (i dalje) raspravlja o Holbeinu? U tom smislu valja formulirati sljedeće hipoteze o načinu na koji je izveden transfer između dvaju romana: 1. Transfer identiteta: Zosima je usporediv s Kristom jer je kristolikost bit njegova identiteta u romanu Braća Karamazovi. 2. Transfer slike i likova: Kristovo tijelo na Holbeinovoj slici Tijelo mrtvoga Krista u grobu preneseno je iz romana Idiot u roman Braća Karamazovi u "ikoničnom" mrtvom tijelu starca Zosime. Uz to tijelo mladi "bogoslov" Aljoša zapravo nastavlja razmišljanja započeta o tijelu na Holbeinovoj slici u romanu Idiot.

Dakle, što pokazuje analiza teksta romana Idiot i Braća Karamazovi u kontekstu tih hipoteza?

\section{Transfer identiteta}

U romanu Braća Karamazovi mogu se prepoznati tri susljedna prijenosa identiteta kojima se otvara put prema suočenju s Holbeinovom slikom Tijelo mrtvoga Krista u grobu. Svi ti prijenosi imaju izravan utjecaj na sudbinu Aljoše Karamazova. On im je ujedinjavajuće središte. U tom se smislu prije svega može govoriti o horizontalnom transferu, tj. prijenosu očinstva posredstvom Bogorodičine ikone (Fjodor Karamazov — starac Zosima), zatim o vertikalnom transferu identiteta (živi Zosima — živi Krist), čime Zosima postaje Kristova ikona. U konačnici, mrtvi Zosima postaje ikona mrtvoga Krista, tj. Holbeinove slike Mrtvi Krist u grobu 
(Zhivolupova, 2012, 330). Mrtvi Zosima time postaje "ikona ikone". Tu se valja usredotočiti osobito na taj treći prijenos (mrtvi Zosima - Tijelo mrtvoga Krista u grobu) analizirajući prva dva prijenosa identiteta u smislu otvaranja puta trećemu i kulminacijskomu.

\subsection{Horizontalni prijenos identiteta, transfer očinstva}

Prvi prijenos identiteta u romanu Braća Karamazovi događa se posredstvom ikone, prelaskom ikone iz ruke u ruku. Fjodor Karamazov daruje Aljoši ikonu pred kojom se je molila njegova majka. Taj čin znači oslobođenje, jer predajući mu ikonu, Fjodor Karamazov dopušta Aljoši da se vrati u manastir, premda mu je to ranije zabranjivao (Dostojevski, 1975b, 159). To je simbolički čin Fjodora Karamazova, kojim on zapravo predaje svoje stvarno očinstvo u ruke starca Zosime, kao novoga Aljošinoga duhovnoga otca te time potvrđuje njihovu povezanost. Ta je gesta ključni trenutak života mladoga iskušenika: ikona Majke Božje koja je pripadala njegovoj majci sada postaje njegovom. Pod zaštitom Majke Božje, kojoj ga je majka preporučila, Aljoša postaje oslobođen za svojega novoga, duhovnoga otca i time kreće na svoj križni put (Ollivier, 2001, 64).

\subsection{Vertikalni prijenos identiteta, transfer Zosima - Krist}

Gotovo svaki detalj odnosa između mladoga iskušenika i njegova starca potvrđuje da Aljoša smatra Zosimu svojim duhovnim otcem u najuzvišenijem smislu. Od samoga je početka romana očito da ga Aljoša smatra i svetcem. Ipak, izuzmu li se emocionalna obrazloženja takve privrženosti, utemeljenje Aljošina uvjerenja o Zosiminoj svetosti nije posve bjelodano. Zašto je dakle za Aljošu starčeva svetost tako neupitna? Odgovor se na to pitanje zasigurno može iščitati iz dviju inačica iste svečane tvrdnje u tekstu romana Braća Karamazov. Prva se pojavljuje na početku, u odjeljku Starci: »Ako je u nas grijeh, laž i napast, ipak postoji ondje, negdje na zemlji netko svet i uzvišeniji od nas; u njemu je zato istina, on zato pozna istinu, dakle ne umire ona na zemlji, nego će možda jednom i nama doći i zavladati na cijeloj zemlji, kako je obećano «(Dostojevski, 1975b, 37). Druga je u Aljošinu "hagiografskom rukopisu", tj. u predsmrtnoj ispovijesti starca Zosime: »Oni [monasi] zasad čuvaju u svojoj samoći lik Kristov (образ Христов) divan i neiskvaren, u čistoći istine Božje, naslijeđen od drevnih otaca, apostola i mučenika, i kada bude potrebno, pokazat će ga poljuljanoj istini svijeta. Ova je misao velika. Od istoka zasjat će ova zvijezda (Dostojevski, 1975b, 345).

Obje tvrdnje uključuju uvjerenje da postoji problem, ali i njegovo rješenje. Problem je poljuljana pravda ovoga svijeta iz druge tvrdnje, odnosno grijeh, laž i napast iz prve tvrdnje. Iz njih također proizlazi da ce svijet postati boljim razotkrivanjem za sada skrivene istine. To se tek treba dogoditi: »ona će valjda jednom i nama doći«, tj. bit će pokazana svijetu. Što, odnosno tko je ta istina u prvoj tvrdnji ostaje neodređeno, a u drugoj je tvrdnji posve jasno: istina je Krist, njegov lik, »divan i neiskvaren«. Nadalje, iz oba iskaza proizlazi da će se ta istina svijetu očitovati neizravno, tj. posredno. Tko će dakle svijetu pokazati tu istinu, tj. 
Krista? Odgovor na to pitanje u prvoj tvrdnji još je relativno neodređen: negdje na svijetu ima netko tko zna istinu, u njega je istina. Iz konteksta druge tvrdnje jasno je da je ta misija povjerena ruskim monasima. Oni ju čuvaju i oni će ju pokazati svijetu. To je dakle zadaća skupine, pa je stoga riječ o množini. No, još se važnijim čini sljedeće pitanje: Podrazumijeva li kontekst prve tvrdnje tu istu tvrdnju o ruskim monasima? Valja prije svega uočiti da je za razliku od druge tvrdnje, tekst prve usmjeren na jedninu. »Netko svet«, a ne neki sveti, »u njega je istina«, a ne u njih, on zna istinu, a ne oni. Tom je gramatičkom jedninom pripremljen teren za ključnu tvrdnju, rečenicu koja slijedi neposredno iza prve tvrdnje. Ondje saznajemo da Aljoša nije ni najmanje dvojio da je »upravo starac taj svetac, taj čuvar pravde Božje« (Dostojevski, 1975b, 37).

Zaključak se usporedne analize tih tekstova mirno može priključiti rijetko usuglašenu mnogoglasju kritike, koja govori o Dostojevskom da »u Zosimi doista vidimo Krista čija je on ikona« (Slattery 1993, 17). Time prva hipoteza izgleda opravdanom. Imajući to u vidu, valja razmotriti argumentaciju za drugu hipotezu: "dvostruki transfer" (slike i likova), prvo prijenos ideja unutar romana Idiot, a zatim i između dvaju romana, Idiot i Braća Karamazovi.

\section{Transfer slike i likova}

\subsection{Transfer ideja unutar romana Idiot}

Transfer ideja između likova u romanu Idiot nije neuobičajena pojava. Uviđajući te paralelizme između kneza Miškina i Ipolita, Sarah Young $(2004,125)$ i Robin Feuer Miller (1981, 200) napomenuli su da Ipolit više govori o Miškinovim idejama nego sâm knez. Štoviše, Ipolit preuzima gotovo sve knezove stožerne ideje. Na tragu takva postupka valja razmotriti sljedeće tri tvrdnje: 1. »Ovakva slika može čovjeka natjerati da izgubi vjeru « (Grossman 1986, 537); 2. »Pa od te slike može čovjek i vjeru izgubiti« (Dostojevski, 1975a, 223); 3. »kako su mogli povjerovati gledajući takav leš, da će taj mučenik uskrsnuti? « (Dostojevski, 1975a, 414).

Analizirajući bilješke Ane Grigorjevne u jednom od izdanja romana Idiot, na prvu od tih tvrdnji upozorio je u svojim predavanjima i biograf Dostojevskoga Leonid Grossman. On je pokazao da je tu rečenicu Dostojevski izgovorio svojoj supruzi kad je u kolovozu 1867. ugledao sliku Tijelo mrtvoga Krista u grobu u Baselu te da se je tom potresnom dojmu što ga je na njega ostavila Holbeinova slika često poslije vraćao (Grossman, 1922, 59). Gotovo posve identična rečenica drugoj prenesena je u roman Idiot: ona predstavlja zaključak kneza Miškina o kopiji te iste slike što ju je on ugledao u Rogožinovoj kući. Ako je dakle vjerovati izvornosti Anina i Grossmanova citata, ta bi gotovo doslovna podudarnost s Miškinovom izjavom mogla biti još jedan izvrstan primjer opravdanosti uvjerenja prvoga biografa Dostojevskoga Nikolaja Strahova, koji je napisao da je u svojim likovima Dostojevski »gotovo bez iznimke slikao samoga sebe«, dodajući: »Za mene, koji sam tako dugo bio u njegovoj blizini, subjektivnost njegovih prikaza 
bila je itekako prepoznatljiva i zbog toga mi je uvijek propadalo pola dojma djelâ koja su na druge čitatelje djelovala zapanjujuće, jer su u njegovim likovima vidjeli savršeno objektivno opisivanje « (Strahov, 1883, 226).

Baš ta očita podudarnost prvih dvaju iskaza nameće pitanje: Ako su ti iskazi o gubitku vjere odgovor tih dviju osoba pred Holbeinovom slikom, što je u tom slučaju pitanje? Što se nalazi u pozadini tih dviju tvrdnji? Na to pitanje odgovara Ipolit u svojoj analizi slike. Upravo u njezinoj sjeni on kao da postavlja upit svih upita: »kako su mogli povjerovati gledajući takvo tijelo, da će taj mučenik uskrsnuti? «(Dostojevski, 1975a, 414). Usporedimo li točke suglasja svih triju tvrdnji, opravdanim se čini zaključak da pred Holbeinovom slikom stradava vjera (kako tvrde prva dva iskaza) upravo zato što izgled mrtvoga Krista dovodi u pitanje vjeru u njegovo uskrsnuće, što iskazuje treća citirana rečenica.

Zanimljivo, sva trojica suočenih s Holbeinovom slikom bolesni su: Anni se čini da bi Dostojevski od toga prizora mogao doživjeti epileptični napad (Dostojevskaja, 1987, 186), Miškinova dijagnoza zapisana je mnogo puta ne samo u tekstu, nego i u naslovu romana u kojem se on pojavljuje, a Ipolit boluje od tuberkuloze i razmišlja o samoubojstvu. Ipak, anamneza je te trojice pred Holbeinovom slikom samo prividno fizička i u svakoga je od njih različita. Zapravo, svi oni boluju od iste bolesti. Ta bolest nije fizička, nego je bolest duha, a njezin bi se izvor mogao nazvati svojevrsnim Pavlovim kategoričkim imperativom: »Ako Krist nije uskrsnuo, uzaludna je vjera vaša « (1 Kor 15,17). Ipolit to sigurno zna, i zato je samo do kraja izgovorio ono što Dostojevski u Baselu i Miškin u romanu Idiot nisu dorekli, pa je Ipolit to učinio u njihovo ime (Ollivier 2001, 66). Njima je dakle očito da Holbeinova slika dovodi u pitanje vjeru u uskrsnuće. Iako neizgovoren, nad tvrdnjama Dostojevskoga u Baselu i Miškina u romanu lebdi isti taj upitnik. Zato je Ipolitovo pitanje (treći iskaz) doista organski povezano s tim tvrdnjama. Je li to doista onaj isti Krist što ga je u zanosu spominjao Zosima, upravo onaj kojega će monasi jednom u budućnosti pokazati pravdi ovoga svijeta? Holbeinov prikaz Krista kao da je negativ te iste Zosimine budućnosti, jer ako je gramatički futur doista »idiom mesijanskoga « (Steiner, 2006, 12), nije li Holbein zapravo naslikao neumoljivi kraj te budućnosti? $\mathrm{Na}$ tu "blasfemičnu misao" u romanu Idiot određeni utjecaj zasigurno ima i onodobna lektira Dostojevskoga, jer je u vrijeme planova za taj roman po drugi put čitao Život Isusov Ernesta Renana. Glavna poruka te utjecajne knjige, sama njezina bit, može se pronaći u njegovu stajalištu o Mariji Magdaleni na Isusovu praznom grobu: »Možemo reći da je snažna mašta Marije Magdalene tu imala temeljnu ulogu. Božanski trenutci ljubavi! Sveti trenutci u kojima strast žene koja halucinira daje svijetu uskrsloga Boga« (Renan, 1891, 356-357).

U podlozi se Miškinovih ili Ipolitovih dvojbi o Kristovu uskrsnuću zasigurno mogu razabrati i tragovi takvih renanovskih refleksija. S druge strane, Dostojevski je već ranije formulirao negativan stav o Renanu i nije ga više mijenjao. Njegovo se zaprepaštenje pred Holbeinovom slikom u Baselu nerijetko tumači razlikama u ikonografskim navikama kršćanskoga Istoka i Zapada, odnosno razlikama između teologije križa i teologije slave (Miščin, 2011, 114). To stajalište 
nije netočno, ali čini se da je ipak važnije nešto drugo, ono što Dostojevskoga vraća u svojevrsnu Renanovu sjenu. Naime, kao što upozorava Jeff Gatrall (2001, 218-219), Holbein zapravo prikazuje samo jedan trenutak u raspadanju osamljenoga leša, i time narativ uskrsnuća dovodi do mrtve točke. To je upravo ono što Christina Farronato naziva užasom prekinutoga narativa, dodajući da Holbein krši Albertijeva načela time što je u potpunosti osamio tijelo umrloga. Odstranjivanjem svih likova koji bi stajali oko Kristova tijela prekinut je Isusov narativ. Krist više nije otkupnina za spas čovječanstva, nego jednostavno »mrtvo ljudsko biće koje je napušteno« (Farronato, 1998, 118).

Iako je takva misao zasigurno dobar trag, čini se da se od Dostojevskoga može naučiti da s Holbeinovom slikom Tijelo mrtvoga Krista u grobu temeljni problem ipak nije u osamljenosti. Zamislimo li da na Holbeinovoj slici Kristovo tijelo još nije položeno u grob, nego okruženo žalobnicima, oporost bi njegove poruke doduše bila donekle ublažena, ali bi izgled njegova tijela i dalje ostao zastrašujući.

To znači da nelagodu o kojoj govore Gatrall i Farronato ne treba povezivati s Kristovom osamljenošću na Holbeinovoj slici, nego sa zastrašujućim stanjem njegova mrtvoga tijela. To mrtvo tijelo doista je kadaver u svojem izvornom značenju. Naime, ta riječ dolazi od latinskoga cadere, što znači pasti. Zato Julija Kristeva ima pravo kad u skladu sa spomenutim podrijetlom riječi kadaver napominje da leš doista predstavlja pad s onu stranu granice, ali bi se isto tako moglo ustvrditi da ta svojevrsna ljuštura bivšega subjekta $u$ isto vrijeme ostaje is ove strane. U toj je dvoznačnosti takav »krnji subjekt« doista nešto »imaginarno strano i kao zbiljska prijetnja, poziva nas i na posljetku nas proždire « (Kristeva 1989, 9).

Pogledamo li iz te perspektive likove iz romana Idiot koji razmišljaju o Holbeinovoj slici, Ipolita, Rogožina i Miškina, čini se da u okrilju toga romana problem slike Tijelo mrtvoga Krista u grobu nije ni mogao biti riješen. Naime, Ipolitov se životni trenutak poklapa s tom napomenom Kristeve: »i na posljetku nas proždire«. On je svjestan da živi posljednje dane svojega života, pa Holbeinova patnika promatra iz neumitne sjene toga suočenja. Ipolitova je vjera ugrožena Holbeinovom slikom, i zato je on utjelovljenje istih onih riječi koje su izgovorili Dostojevski u Baselu i Miškin u istom romanu. Ipolit je dakle cilj dvostrukoga transfera, ali se te misli u njemu intenziviraju, jer ono što su njihove riječi, njegov je život. Ipolit u Holbeinovoj slici i tim riječima vidi svoju neposrednu budućnost, i toj misli doista ni na koji način ne može umaknuti. Kako komentira Kenneth Lantz (2004, 204), Ipolit doduše tvrdi da može prihvatiti ideju o besmrtnosti, ali ju prihvaća samo intelektualno i načelno. Tako je besmrtnost za njega tek neka vrsta slabe i upravo očajničke ideje. Zato je osuđen gledati u Holbeinovu sliku kao u ogledalo u kojem vidi vlastito užasnuto lice, kao pred smaknuće, baš onakvo kakvo opisuje Miškin na početku romana.

Problem Holbeinove slike u romanu Idiot ne mogu riješiti ni druga dvojica likova koji se dotiču te slike. Ne mogu to ni Rogožin, jer je okrvavio ruke, ni Miškin, jer njegove ruke nisu odveć djelatne, unatoč svoj njegovoj plemenitosti. Nije li mnogo više od simbolike to što Miškin, jedini lik koji je vidio Holbeinov 
original, na kraju toga romana prvo ostaje uz mrtvo tijelo Nastasje Filipovne, zajedno s Rogožinom, koji posjeduje kopiju Holbeinove slike? Štoviše, nema li tama u kojoj se uz to tijelo zatječu Rogožin i Miškin ipak nešto zajedničko s tminom groba s Holbeinove slike: Rogožinova postelja, na koju je položio Nastasjino tijelo, zastrta je teškim zastorom i svi su ulazi do nje zatvoreni. U sobi vlada mrtva tišina i vrlo je mračno (Dostojevski, 1975a, 611), unatoč tomu što vani još uvijek traju petrogradske bijele noći. Miškinu je premalo svjetla u toj tmini, ali Rogožin odbija upaliti svijeću. To odbijanje kao da ukazuje na to da ta dvojica u mraku zapravo dijele Ipolitovu sudbinu pred prikazom mrtvoga Krista s Holbeinove slike, jer čini se da ni za njih, uz mrtvo tijelo Nastasje Filipovne, nema nade u svjetlo koje bi moglo rastjerati tminu u kojoj su se našli. I doista, kad knez pristupa Nastasjinu tijelu, on iznova naglašava: »tu je mrak!«. Simbolički, nad krajem romana Idiot nadvio se je mrak i nije se razdanilo. Još jednom, u činjenici da je Ipolit na koncu izdahnuo strahovito potresen (Dostojevski, 1975a, 618) znatan je udio njegove refleksije o Holbeinovoj slici. Uz to, simbolično je da se Miškin na kraju romana vraća odakle je došao, u sanatorij u Švicarsku, domovinu Holbeinove slike.

Na temelju izrečenoga zasigurno se može zaključiti da problem slike Tijelo mrtvoga Krista u grobu na stranicama romana Idiot nije riješen, a iz navedenih razloga čini se da nije ni mogao biti. Taj je problem ondje tek zaoštren. U svjetlu tih okolnosti valja razmotriti sljedeću razinu transfera slike i likova, ne više unutar istoga teksta, nego između dvaju romana. Taj transfer mogao bi biti posljedica nemirenja Dostojevskoga s nezaključenošću Holbeinove slike u romanu Idiot.

\subsection{Transfer ideja i likova između romana Idiot $i$ Braća Karamazovi}

Upravo u svjetlu toga nemirenja, valja usporediti dvije tvrdnje: jedna je Ipolita u romanu Idiot, a druga je Aljoše u romanu Braća Karamazovi.

Ipolit o Holbeinovoj slici Tijelo mrtvoga Krista u grobu naglašava sljedeće: »Dok gledaš tu sliku, priviđa ti se priroda u liku nekakve goleme, neumoljive i nijeme zvijeri, ili točnije, kudikamo točnije rečeno, premda je i čudno - u obliku nekog orijaškog stroja najmodernije konstrukcije koji je glupo zahvatio, zdrobio i progutao, nesmiljeno i bešćutno, veliko i dragocjeno biće - biće koje samo za se vrijedi koliko i svekolika priroda i svi njeni zakoni, svekolika Zemlja, koja je možda jedino radi toga stvorena da bi se to biće moglo pojaviti! Tom slikom baš kao da je izražena ta spoznaja o mračnoj, bezobzirnoj i besmisleno vječnoj sili kojoj se pokoravaš i protiv svoje volje« (Dostojevski, 1975a, 414).

U istom duhu, Aljoša prosvjedujući zbog zadaha Zosimina tijela izjavljuje u romanu Braća Karamazovi: »I eto, onaj koji je imao biti, kako se on nadaše, uzvišen nad sve na cijelom svijetu - upravo taj, mjesto da bude po zasluzi uzvišen, bio je odjedanput ponižen i osramoćen! Zašto? Tko je tako presudio? [...] On nije mogao podnijeti bez boli, čak bez srdžbe u srcu, što je najpravedniji među pravednicima izvrgnut takvoj podrugljivoj i pakosnoj sprdnji lakoumne rulje koja je bila toliko niža od njega. Dobro, neka se i ne dogodi čudo uopće, neka se ne 
desi ništa čudno i neka se ne ispuni ono što se odmah očekivalo — ali zašto je moralo doći do onog obeščašćenja, zašto je dopuštena sramota, zašto to naglo truljenje koje je 'preteklo prirodu' [...] Gdje je providnost i njezin prst? Zašto je ona sakrila svoj prst u 'najpotrebnijem trenutku' (mislio je Aljoša) i kao da se sam htio potčiniti slijepim, nijemim, nemilosrdnim zakonima prirode? « (Dostojevski, 1975c, 21).

Tomu citatu treba dodati još dvije Aljošine riječi koje neposredno slijede i koje su pravi sažetak toga prosvjeda. Aljoša naime pati zato što je tijelo čovjeka kojega on voli i drži svetim doslovno »lišeno slave« (Dostojevski, 1975c, 21). Čini se da je baš taj prizvuk kenoze bez ostatka čvrsto povezan s temeljnim doživljajem Dostojevskoga pred Holbeinovom slikom, baš kao i uz narativ o toj slici u romanu Idiot. Zato izgleda da bi Aljošin diskurs o Zosiminu mrtvom tijelu doista trebalo promatrati u vezi sa spomenutim elementom iz biografije Dostojevskoga, odnosno njegova ranijega romana.

Sličnost se dvaju iskaza, Ipolitova u romanu Idiot i Aljošina u romanu Braća Karamazovi, pokazuje višestrukom i može ju se prepoznati na četirima razinama:

a) Temeljni argument: bešćutnost prirode prema mrtvomu tijelu uzvišenoga bića (Ipolit i Aljoša), bez obzira na to obrušava li se ona na tijelo pokojnika izravno, tj. bez posrednika (Ipolit), ili pak posredno, jer se je skrio prst Providnosti (Aljoša).

b) Svojstva prirode u odnosu na mrtvo tijelo: u prvom slučaju ta se svojstva opisuju pridjevima »golema, neumoljiva i nijema« te »nesmiljena i bešćutna« (Ipolit), a u drugom »slijepa, nijema i nemilosrdna« (Aljoša). Analiza tih dvaju nizova pokazuje sljedeće: isti pridjev u oba iskaza: priroda je »nijema« (Ipolit i Aljoša) te vrlo slični pridjevi: priroda je »neumoljiva« i »bešćutna« (Ipolit) odnosno »nemilosrdna « (Aljoša). Valja također napomenuti da se zajedno sa zadahom Zosimina tijela širi opći i višestruko opetovani stav javnoga mnijenja da je zadah »pretekao prirodu«. Spomen prirode u tom kontekstu izveden je i kod Ipolita i kod Aljoše iz istoga argumenta o njezinoj »mehanicističkoj bešćutnosti«. Oba se ta pitanja mogu svesti na isto, temeljno pitanje o smislu Kristove smrti: Zašto su ta dva sveta tijela, Kristovo i Zosimino, morala biti podvrgnuta takvomu “ispražnjavanju”, tomu posmrtnomu opustošenju? U nastavku Ipolitove analize slike nalazi se zanimljiva primjedba: njemu se čini da lice mrtvoga Krista na Holbeinovoj slici odiše mukom kao da ju on još trpi (Dostojevski, 1975a, 413).

c) Superiornost mrtvoga Krista: u oba su slučaja strvena bića superiorna drugim bićima, bilo da je ta superiornost ontološka (»veliko i neprocjenljivo biće — takvo biće koje bi samo samcato vrijedilo koliko i svekolika priroda i svi njeni zakoni«, Ipolit), ili etička (»najpravedniji među pravednicima«, Aljoša). U Zosiminu slučaju Aljoša naravno ne može pribjeći ontološkomu argumentu (utoliko što Ipolit govori o božanskom, a Aljoša o ljudskom biću), ali naglašavajući Zosiminu etičku superiornost, on mrtvoga Krista također čini eminentnim drugim bićima, baš kao i Ipolit.

d) Rezultat - poraz mrtvoga Krista: na tragu prethodno ustanovljene razlike, iz ontološkoga argumenta slijedi metafizički epilog o besmislu jer je priroda 
(neizravno) »nesmiljena« i »bešćutna« (Ipolit), a iz etičkoga argumenta slijedi etički epilog o sramoti koja uzrokuje srdžbu (Aljoša).

U kontekstu i na tragu svih tih preklapanja, valja se još jednom vratiti prvomu dijelu netom citirane Aljošine lamentacije nad Zosiminim mrtvim tijelom: »Ali eto, onaj koji je prema njegovim nadanjima, trebalo da se uzvisi iznad svih na svijetu - taj je isti, umjesto slave koja mu pripada, iznenada oboren i osramoćen. Zbog čega? Tko ga je na to osudio? Tko je mogao tako presuditi? « Doista, cijeli bi se Aljošin problem u tom trenutku mogao izvesti iz jednostavnoga »psalamskoga silogizma«. On bi naime rado prihvatio uzvišeni, upravo "viteški” naputak: »Jer mi nećeš ostavit dušu u podzemlju, ni dati da pravednik tvoj truleži ugleda « (Ps 16,10). Zosimu je pak ta ista trulež spomenuta u psalmu pohodila i više no doslovno. Zaključak je jednostavan: budući da je prepušten truleži, Zosima nije pravednik, tj. svetac. Naravno, raspadanje Kristova tijela na Holbeinovoj slici Ipolita dovodi do sličnoga rezigniranoga zaključka o nemogućnosti njegova uskrsnuća.

Ni Aljošina ni Ipolitova tuga pred inačicama i implikacijama njihovih uvida nipošto nije isključivo pravoslavna, a ni ruska. Štoviše, bilo bi točnije ustvrditi da je njih dvojicu snašla zapravo ekumenska tuga. Na zajedništvo bi se kršćanskoga Istoka i Zapada moglo ukazati i podsjećanjem na razmišljanja Tome Akvinskoga, koji jasno tvrdi kako zbog očitovanja njegova božanskoga dostojanstva nije prikladno da se Kristovo tijelo raspada. Raspravljajući o tom problemu u svojem najopsežnijem djelu Summa theologiae, Toma nastavlja da bi podložnost Kristova tijela raspadanju »bila štetna za čovjekovo spasenje, jer tada ne bi izgledalo da je u njemu Božanska moć« (STh III, q. 51, a. 3). S druge strane, Toma je dovoljno oprezan da, tvrdeći to, izbjegne očitoj zamci: ako je Krist doista čovjeku »jednak u svemu osim u grijehu « (jer je pravi čovjek), zašto bi njegovo tijelo bilo izuzeto od raspadanja? U poslovično preciznom odgovoru na sličan prigovor, Toma odgovara da je u skladu s njegovom ljudskom naravi to tijelo doista moglo biti predmetom raspadanja, ali je Božjom intervencijom ono ipak sačuvano od raspadanja (STh III, q. 51, a. 3), i time je potvrđena njegova svetost. Traže li Ipolit pred Holbeinovom slikom i Aljoša pred Zosiminim tijelom išta više od potvrde toga Tomina zaključka?

Baš zbog toga suglasja čini se da Ipolitovo i Aljošino razmišljanje u bitnom i nije toliko različito. Drugim riječima, pokazuje se da su Ipolitov diskurs i Aljošin prosvjed međusobno zamjenjivi. Ako su doista zamjenjivi, ne nastavlja li Dostojevski, služeći se Aljošinim ustima, govoriti o Holbeinovoj slici Tijelo mrtvoga Krista u grobu? Time se nipošto ne iscrpljuju sve analogije između Ipolitova i Aljošina diskursa, a to znači ni razlozi u prilog tezi da je u romanu Braća Karamazovi kao »romanu loših mirisa « (Jones, 1985, 317) Holbeinova slika iz romana Idiot nastavila zjapiti u svijet skrivena u mrtvo tijelo starca Zosime. U tom smislu, Holbeinova slika nije tek jedna od umjetnina kojom bi, kao nekom pridodanom "estetičkom skicom", Dostojevski ukrašavao stranice svojih kasnijih romana. To je upravo temeljno sredstvo kojim zreli i zalazni Fjodor Mihajlovič nastavlja refleksiju o besmrtnosti, ili ju čak dovodi do njezina vrhunca. Imajući u vidu sva 
spomenuta ograničenja s kojima je bila suočena rasprava o Holbeinovoj slici Tijelo mrtvoga Krista u grobu u romanu Idiot, ta slika Dostojevskomu treba i u romanu Braća Karamazovi, koliko god ondje bila skrivena. Imajući u vidu taj kontinuitet slike (Holbein) i problema (besmrtnost, uskrsnuće) u opusu Dostojevskoga čini se da Gary Saul Morson $(2014,11)$ ima potpuno pravo čvrsto povezujući “obrnuto čudo" ubrzanoga raspadanja Zosimina tijela u romanu Braća Karamazovi, ne toliko s pojedinačnim mislima Aljoše Karamazova, koliko s problemom ugrožavanja eshatoloških nada uopće. Naravno da se, valja to još jednom naglasiti, pritom otvaraju dva vrlo široka pitanja. Prvo bi moglo glasiti: Dopušta li čitanje romana Braća Karamazovi ikakvu slutnju o mogućem ispunjenju tih eshatoloških nada? Odgovor se može naslutiti u vazmenom naboju Aljošina govora na kraju romana. Drugo je još opsežnije pitanje o odnosu između interpretacije Holbeinove slike Tijelo mrtvoga Krista u grobu i problema Kristove kenoze, kako ju daje Dostojevski. Iako su oba ta pitanja izrazito važna i teorijski upravo monumentalna, ovaj se ogled ograničava tek nakanom ukazivanja na razloge koji potvrđuju da je Dostojevski "potajice" prenio problem Holbeinove slike iz jednoga u drugi svoj roman. S obzirom na tako postavljen cilj, jasno je zbog čega su tomu diskursu Nietzscheova pitanja bliža od primjerice teološki uznositih odgovora Hansa Ursa von Balthasara.

Valja podsjetiti na to da je Nietzsche, koji je u mladosti bio i baselski sveučilišni profesor, na možda najpoznatijem mjestu svojega opusa, na usta bezumnika u knjizi Die fröhliche Wissenschaft ("Radosna znanost"), upozorio da je Bog mrtav i da smo ga mi ubili. On ujedno napominje da se zemlja otkovala od svojega sunca te da postaje sve hladnije. Taj prorok kraja svijeta koji je nekad bio domom, kao usput, dodaje: »Ne osjećamo li još ništa od božanskog raspadanja? — i bogovi trule « (Nietzsche, 1999, 481). Ta Nietzscheova opora tvrdnja dodatno ohrabruje pomisao da se iz primarne analogije (živi Zosima kao ikona živoga Krista) doista može izvesti i druga, analogija između mrtvoga Zosimina i Kristova tijela. Naime, vrlo je upadljivo da ta dva tijela povezuje isto neugodno svojstvo: i Kristovo tijelo na Holbeinovoj slici i Zosimino tijelo u romanu Braća Karamazovi nedvojbeno pokazuju prve znakove raspadanja.

Ako je dakle Holbein naslikao upravo taj problem, raspadanje tijela božanskoga bića, onda Dostojevski opisom raspadanja tijela starca Zosime zapravo ne ispisuje samo posmrtnu biografiju jednoga izmišljenoga i tim zadahom osporenoga svetca, nego tim istim tijelom nastavlja misliti holbeinovsku misao. Analogijom tih dvaju tijela, Kristova i Zosimina, Dostojevski zapravo nastavlja onu istu baselsku misao iz kolovoza 1867. i sa stranica romana Idiot. Čini i korak više: $\mathrm{Ne}$ nalazimo li se, suočeni s raspadanjem tih dvaju tijela, pred pravim negativom one iste "velike misli" o svečanom iščekivanju trenutka kad će monasi pokazati svijetu Krista? Ako je dakle Zosima za života bio Kristova ikona, tada bi se njegovo mrtvo tijelo doista moglo razumijevati i kao svojevrsna ikona Kristove "ikone" iz Basela. To je ključni zaključak koji proizlazi iz prethodne rasprave o problematici transfera, prvo unutar romana Idiot, a zatim, što je još važnije, i između romana Idiot i Braća Karamazovi. 


\section{Zaključak}

Prethodna rasprava sadrži argumentaciju za premise iz kojih slijede ova četiri zaključka:

1. Ključna mjesta na kojima se u dvama romanima tematizira taj problem (Ipolitova refleksija o Holbeinovoj slici Tijelo mrtvoga Krista u grobu u romanu Idiot i Aljošin prosvjed nad mrtvim Zosimom) pokazuju izrazitu terminološku, tematsku i idejnu sličnost (usp. podpoglavlje 2.2. Transfer ideja i likova između romana Idiot i Braća Karamazovi).

2. U prvom dijelu romana Braća Karamazovi Dostojevski priprema "prijenos tijela", tj. "skrivanje" Holbeinova prikaza tijela mrtvoga Krista u svoj prikaz mrtvoga tijela starca Zosime. To čini dvama odlučnim "transferima”, kojima je u središtu Aljoša Karamazov: prvo horizontalnim transferom očinstva s njegova fizičkoga otca (Fjodor) na njegova duhovnoga otca (Zosima), a zatim i vertikalnim transferom, tj. srastanjem Zosimina lika s likom Krista. Vertikalnim je transferom omogućen prikriveni prijenos slike i problema Holbeinove slike iz romana Idiot u roman Braća Karamazovi (usp. podpoglavlje 2.1. Transfer ideja unutar romana Idiot).

3. Pristup Dostojevskoga Holbeinovoj slici u romanu Idiot i mrtvomu tijelu starca Zosime u romanu Braća Karamazovi određen je istim, temeljnim problemom. U oba slučaja Dostojevski se bavi moralnom i metafizičkom dopustivošću ispražnjavanja dostojanstva uzvišenoga, svetoga bića (Krist, Zosima). Vanjski je znak toga "lišavanja slave" u oba slučaja propadanje mrtvoga tijela. U pozadini obje te refleksije može se prepoznati isto pitanje: problem Kristove kenoze (usp. podpoglavlje 2.2. Transfer ideja i likova između romana Idiot i Braća Karamazo$v i)$.

4. Imajući u vidu sve te elemente, potvrđuje se polazišna hipoteza te se može zaključiti da je problematika Zosimina mrtvoga tijela Dostojevskomu sredstvo za nastavak rasprave o Holbeinovoj slici Tijelo mrtvoga Krista u grobu započetoj u romanu Idiot. Drugim riječima, u Zosiminu mrtvom tijelu zapravo je skriven onaj isti Holbeinov prikaz mrtvoga Krista iz romana Idiot o kojem se u romanu Braća Karamazovi nastavlja raspravljati.

\section{Literatura}

Biblija. Jure Kaštelan i Bonaventura Duda (ur.), Biblija: Stari i Novi zavjet. Zagreb: Kršćanska sadašnjost, 1995.

Bitjugova, I. A, Viktorovič, V. A., Kijko E. I., Ornatskaja T. I. (1999). И. А. Битюгова, В. А. Викторович, Е. И. Кийко, Т. И. Орнатская, Летопись жизни и творчества p. М. Достоевского, том второй 1865-1874. Санкт-Петербург: Издательство Академический проект.

Dostojevskaja, Anna G. (1987). Анна Григорьевна Достоевская, Воспоминания. Москва: Издательство Правда.

Dostojevski, Fjodor Mihajlovič (1975a). Idiot. Zagreb: Znanje.

Dostojevski, Fjodor Mihajlovič (1975b). Braća Karamazovi: Prvi i drugi dio. Zagreb: Znanje. 
Dostojevski, Fjodor Mihajlovič (1975c). Braća Karamazovi: Treći i četvrti dio te epilog. Zagreb: Znanje.

Farronato, Christina (1998). Holbein's Dead Christ and the horror of broken narrative. Interdisciplinary Journal for Germanic Linguistic and Semiotic Analysis, 3(1), str. $121-140$.

Feuer Miller, Robin (1981). Dostoevsky and The Idiot: Author, Narrator, and Reader. Cambridge: Harvard University Press.

Gatrall, Jeff (2001). Between iconoclasm and silence: Representing the Divine in Holbein and Dostoevskii. Comparative Literature, 53(3), 214-232.

Grossman, Leonid Petrovič (1922). Леони́д Петрович Гроссман, Семинарии по Достоевскому: материаль, библиография и комментарии. Москва, Петроград: Государственное издательство.

Grossman, Leonid (1986). Najvažniji datumi iz života i stvaralaštva F. M. Dostojevskoga. U: Fjodor Mihajlovič Dostojevski, Bijedni ljudi (str. 495-563). Zagreb: Znanje.

Jones, John (1985). Dostoevsky. Oxford: Oxford University Press.

Karamzin, Nikolaj (1984). Никола́й Миха́йлович Карамзин, Письма русского путешественника, Ленинград: Наука.

Kristeva, Julija (1989). Moći užasa: Ogledi o zazornosti. Zagreb: Naprijed.

Lantz, Kenneth (2004). The Dostoevsky Encyclopedia. London: Greenwood Press.

Miščin, Daniel (2011). U potrazi za svetim: Svjetlo s Istoka i imanencija transcendencije. Zagreb: Školska knjiga.

Morson, Gary Saul (2004). The God of Onions. U: Robert Louis Jackson (ur.), A New Word on Brothers Karamazov (str. 107-124). Evaston: Northwestern University Press.

Nietzsche, Friedrich (1999). Morgenröte: Idyllen aus Messina: Die fröhliche Wissenschaft. München: Gruyter.

Ollivier, Sophie (2001). Icon in Dostoevsky's work. U: George Pattison i Diane Oenning Thompson (ur.), Dostoevsky and the Christian Tradition (str. 51-68). Camnridge: Cambridge University Press.

Renan, Ernest (1891). Life of Jesus. New York: G. W. Dillingham.

Slattery, Dennis Patrick (1993). Corrupting corpse vs. reasoned abstraction: The play of evil in The Brothers Karamazov. Dostoevsky Studies, 1(1), 3-24.

Steiner, Georg (2006). Gramatike stvaranja. Zagreb: Antibarbarus.

Strahov, Nikolaj (1883). Никола́й Никола́евич Стра́хов, Біографія, письма и замътки изъ записной книжки Ф. М. Достоевскаго. Санкт-Петербург: Туипографія А. С. Суворина.

Toma Akvinski (1988). Summa theologiae. Milano: Editiones Paulinae.

Young, Sarah (2004). Dostoevsky's The Idiot and the Ethical Foundations of Narrative: Reading, Narrating, Scripting. London: Anthem Press.

Zhivolupova, Natalia (2012). Dostoevsky's concept of Holy Body in the structure of The Brothers Karamazov. Macabea: Revista Eletronica do Netlli, 1(2), 321-333. 
Reflections of Holbein's painting The Body of the Dead Christ in the Tomb in the novels The Idiot and The Brothers Karamazov by Fyodor M. Dostoevsky

Daniel Miščin*

\section{Summary}

Hans Holbein's painting The Body of the Dead Christ in the Tomb greatly influenced Dostoevsky's reflections on the possibility of the Resurrection in his late works. The painting is the subject of direct and intense reflection in the novel The Idiot, and the discussion on Holbein's Dead Christ is usually limited to this novel. In the article, however, the author examines the hypothesis that Dostoevsky did not conclude his discussion on Holbein's Dead Christ in the Tomb in The Idiot. A comparative analysis of the two novels seems to allow for the possibility that Dostoevsky's discussion on Elder Zosima's dead body is in fact a continuation of Dostoevsky's discussion on Holbein's Dead Christ.

Key words: Fyodor Dostoevsky; Hans Holbein; The Idiot; The Brothers Karamazov; kenosis; Christ, death 